\title{
Chemical Composition and Antioxidant Properties of Five White Onion (Allium cepa L.) Landraces
}

\author{
Loredana Liguori, ${ }^{1}$ Rosa Califano, ${ }^{1}$ Donatella Albanese, ${ }^{1}$ Francesco Raimo, ${ }^{2}$ Alessio \\ Crescitelli, ${ }^{3}$ and Marisa Di Matteo ${ }^{1}$ \\ ${ }^{1}$ Department of Industrial Engineering, University of Salerno, Via Giovanni Paolo II 132, 84084 Fisciano, Italy \\ ${ }^{2}$ Horticulture Research Center (CRA-ORT), Via Cavalleggeri 25, 84098 Pontecagnano Faiano, Italy \\ ${ }^{3}$ Institute for Microelectronics and Microsystems (IMM) of the National Council of Research (CNR), \\ Via Pietro Castellino 111, 80131 Napoli, Italy \\ Correspondence should be addressed to Donatella Albanese; dalbanese@unisa.it
}

Received 25 July 2016; Revised 25 October 2016; Accepted 7 November 2016; Published 15 January 2017

Academic Editor: Amy Simonne

Copyright (c) 2017 Loredana Liguori et al. This is an open access article distributed under the Creative Commons Attribution License, which permits unrestricted use, distribution, and reproduction in any medium, provided the original work is properly cited.

\begin{abstract}
Five onion landraces belonging to Bianca di Pompei cv., cultivated in Campania region (Italy), were characterized for their main quality parameters. The onion landraces were harvested at the end of the growth cycle corresponding to the ripening time and harvest month, respectively: February, March, April, May, and June. The total content of volatile compounds as well as the sulfurcontaining compounds in Aprilatica was significantly $(p \leq 0.05)$ higher than the other landraces investigated. The nutraceutical feature investigated through the total phenols, phenols profile, and antioxidant activity showed higher values for the samples harvested in spring months. High pungency values ranging from 9 to $14 \mu \mathrm{mol} / \mathrm{g} \mathrm{FW}$ were found in all onion landraces investigated as enzymatically (alliinase) produced pyruvate (EPY). The organic acids profile (malic, citric, succinic, pyruvic, oxalic, ascorbic, and tartaric acids) highlighted malic and citric acids in higher amounts in all landraces. Fructose, glucose, and sucrose were found as soluble sugars and fructose was the most abundant. Generally, the results highlighted the growth temperature influence on the investigated quality parameters.
\end{abstract}

\section{Introduction}

Onion (Allium cepa L.) is the most widely cultivated species of the genus Allium [1].

The plant portion commonly used is the bulb, which is utilized as a food ingredient to give flavour and aroma to a great variety of dishes.

Onions are an important source of several phytonutrients as flavonoids, fructooligosaccharides (FOS), and thiosulfinates and other sulfur compounds, recognized as important elements of the Mediterranean diet [2].

In fact, onions contain high levels of phenolic compounds, which have antioxidant properties besides beneficial effects against different degenerative pathologies (cardiovascular and neurological diseases, dysfunctions based on oxidative stress) [3].

Flavonoids are the major phenolics in onions, which can be classified to different subclasses (flavones, flavanones, flavonols, isoflavones, flavanonols, flavanols, chalcones, and anthocyanins) on the basis of the degree of unsaturation and the degree of oxidation of the central ring. Flavonoids subclasses can be further differentiated on the basis of the number and nature of substituent groups attached to the rings [4].

Flavonols are the most abundant in onions, present as their glycosides, that is, quercetin and kaempferol $[5,6]$, in higher concentration $(280-400 \mathrm{mg} / \mathrm{kg}$ ) than other vegetables (i.e., $100 \mathrm{mg} / \mathrm{kg}$ in broccoli, $50 \mathrm{mg} / \mathrm{kg}$ in apple) [7]. Anthocyanins, belonging to anthocyanidins, are mainly present in red onions $(250 \mathrm{mg} / \mathrm{kg}$ ), besides having a composition rich in flavonols as yellow onions [7].

FOS represent another source of phytochemicals in onions bulbs. They are mainly inulin, kestose, nystose, and fructofuranosylnystose. The health benefits of these carbohydrates have been widely reported in the past years due to their prebiotic effect [8]. 
In onions, sulfur compounds are responsible for typical odour and flavour and are also active antimicrobial agents [9]; hence, onions may be used as natural preservatives to control microbial growth [10]. Furthermore, they have also protective effects against cardiovascular diseases.

The precursors of sulfur-containing compounds are Salk(en)yl-L-cysteine sulfoxides (ACSOs, i.e., methiin, propiin, and isoalliin) which are hydrolysed by means of alliinase enzyme into pyruvate, ammonia, and a mixture of both volatile and nonvolatile sulfur compounds [11], after the breakage of the tissue caused by cutting, mastication, and cooking.

The concentration of pyruvate produced by alliinase activity allows assessing the pungency of onions $[12,13]$. The major flavour compounds are generated by spontaneous reactions of the sulfenic acids. These latter undergo rearrangement to form a mixture of sulfur-containing compounds (S-compounds) including thiosulfinates, thiosulfonates, and mono-, di-, and trisulfides as well as specific compounds such as thiopropanal S-oxide, the lachrymatory or tear factor, all responsible for the typical flavour of onions [3].

The bioaccumulation of organosulfur compounds in onions depends on different factors but especially on the sulfurbased fertilization, the environment, and the genotype of the cultivars [14-16]. Also, other compounds such as organic acids and sugars can contribute to the sensory profile of onions. Hence, organic acids influence the acidity and $\mathrm{pH}$ of the onion juice in a larger or smaller degree; the soluble sugars influence the sweetness of onions and hence the acceptability of this vegetable by consumers. In fact, there is increasing interest in the role that some nonstructural carbohydrates play in the taste preference [17].

Onion (Allium cepa L.) is an Allium vegetable widely cultivated in Campania region (South Italy), in particular in the two contiguous areas of Nocerino-Sarnese and StabieseVesuvius plains, where Bianca di Pompei cultivar is mostly present. This cultivar is actually composed of a set of locally named landraces, all sharing common shapes and colours (white-greenish flattened bulbs). The landraces differ mainly in the bulb harvest time that is a function of the end of the growth cycle and so of the ripening time; the latter ranges from February to June. In this way, the farmer can supply a fresh product for a long time on the market, avoiding problems and costs due to the preservation [18]. The aim of this paper was to characterize different onion landraces belonging to Bianca di Pompei cv in terms of main quality parameters for this crop (volatile compounds, organic acids, sugars, polyphenols, antioxidant activity, and pungency).

\section{Materials and Methods}

2.1. Onion Samples. Raw onions (Allium cepa, Bianca di Pompei cv) were supplied by factories located in the Salerno area (Campania region, Italy). White onion landraces were harvested at the end of the growth cycle and classified according to the harvest month: Febbrarese, Marzatica, Aprilatica, Maggiaiola, and Giugnese reaped in February, March, April, May, and June, respectively. The production of the five white onion landraces was carried out using the conventional cultivation methods for this crop. The bulbs were stored in the dark at $7^{\circ} \mathrm{C}$ for a maximum of 5 days before analysis.

2.2. Chemicals. Analytical grade chemicals, methanol, dichloromethane, trichloroacetic acid, acetic acid, acetonitrile, sodium hydroxide, Folin-Ciocalteu reagent, gallic acid, 2,2diphenyl-1-picrylhydrazyl (DPPH), dinitrophenyl hydrazine (DNPH), quercetin, kaempferol, 2-octanol, sodium sulfate, and ferulic and chlorogenic acids, were purchased from Sigma-Aldrich (St. Louis, MO, USA).

2.3. Extraction of Volatile Compounds. One hundred grams of edible part of onion samples was homogenized in an Ultra-Turrax blender (T25, IKA Werke, Staufen, Germany) at room temperature. The slurry was transferred into the flask with $300 \mathrm{~mL}$ of distilled water and $1 \mu \mathrm{L}$ of 2 -octanol, as internal standard, and sonicated at $50 \mathrm{~Hz}$ for 30 minutes. Ice was added to the ultrasonic bath (Sonica $22000 \mathrm{MH}$, Soltec, Italy) to avoid matrix heating phenomena. The slurry was subjected to steam distillation by a vertical steam distillation unit. The flask containing the homogenized onion was heated for $3 \mathrm{~h}$ and the condensed vapour was extracted with fresh dichloromethane 3 times by separatory funnel. The organic phases were collected, dehydrated with anhydrous $\mathrm{Na}_{2} \mathrm{SO}_{4}$, filtered through Whatman filter paper, and finally concentrated using a Kuderna-Danish device.

2.4. GC-MS Analysis. The volatile compounds were determined by GC-MS (Trace MS plus, Thermo Finnigan, USA) and by GC-FID (HP 6890, Agilent), both equipped with a capillary column (SUPELCOWAX 10;60 m, $0.25 \mathrm{~mm}$, and $0.25 \mu \mathrm{m}$, Supelco, USA). Chromatographic separation was performed on $2 \mu \mathrm{L}$ of sample, using helium as carrying gas at constant flow of $1 \mathrm{~mL} / \mathrm{min}$. The temperature program was as follows: $3 \mathrm{~min}$ at $40^{\circ} \mathrm{C}$, first ramp at $2^{\circ} \mathrm{C} / \mathrm{min}$ to $150^{\circ} \mathrm{C}$, second ramp at $4^{\circ} \mathrm{C} / \mathrm{min}$ to $220^{\circ} \mathrm{C}$, and $10 \mathrm{~min}$ at $220^{\circ} \mathrm{C}$. The GC injector was held at $40^{\circ} \mathrm{C}$ for $3 \mathrm{~min}$, and the column temperature program increased up to $150^{\circ} \mathrm{C}$ at $2^{\circ} \mathrm{C} / \mathrm{min}$, from $150^{\circ} \mathrm{C}$ to $220^{\circ} \mathrm{C}$ at $4^{\circ} \mathrm{C} / \mathrm{min}$ (held for $10 \mathrm{~min}$ ). Detector and transfer line were held at $250^{\circ} \mathrm{C}$. The identification of volatile compounds was carried out by injection of commercial standards (SigmaAldrich, Milano, Italy), by spectra comparison using the NIST and Wiley libraries, and by comparison of their retention indices to reference data from the literature. The quantitative analyses were done assuming the response factors equal to the 2-octanol, used as internal standard [19].

2.5. Polyphenols. $150 \mathrm{~mL}$ of methanol was added to $50 \mathrm{~g}$ of fresh onion tissue. The resulting mixture was homogenized and stirred for 30 minutes; homogenates were held for $15 \mathrm{~min}$ in an ultrasonic bath (Fungilab Ultrasound, Barcelona, Spain) and the extract was separated from the residue by centrifugation at $1900 \times \mathrm{g}$. Extraction was repeated increasing the stirring time to $60 \mathrm{~min}$ and to $90 \mathrm{~min}$. The combined methanol : water extracts were filtered through a Whatman No. 2 filter paper and were evaporated at $40^{\circ} \mathrm{C}$ (rotary evaporator IKA RV-8, Staufen, Germany) to remove methanol. The extracts 
were redissolved in $10 \mathrm{~mL}$ of methanol [5] and were used for the determination of polyphenols and antioxidant activity.

Total phenols were estimated by Folin-Ciocalteu colourimetric assay [20] and results were expressed as mg equivalent gallic acid (GAE)/g dry weight. The absorbance of solutions was read at $765 \mathrm{~nm}$ using a UV-Vis spectrophotometer (Lambda Bio 40; PerkinElmer, Waltham, MA, USA), after 2 hours of incubation in the dark.

The quali-quantitative profile was determined by HPLC (1100, Agilent, Waldbronn, Germany) according to Cinquanta et al. (2015). The polyphenol extracts were filtered through $0.45 \mu \mathrm{m}$ filter syringe and directly injected into Agilent/ HP1100 system (CA, USA). The phenolic compounds were separated on Supelco Ascentis RP-Amide Columns $\mathrm{C}_{18}(150 \times$ $4.6 \mathrm{~mm} ; 5 \mu \mathrm{m})$ at a flow rate of $1.2 \mathrm{~mL} / \mathrm{min}$. The mobile phase used was (A) water/acetic acid $(99: 1, \mathrm{v} / \mathrm{v})$ and (B) acetonitrile/acetic acid $(99: 1 \mathrm{v} / \mathrm{v})$, with a gradient as follows: $0 \mathrm{~min}, 100 \% \mathrm{~A} ; 6.5 \mathrm{~min}, 85 \% \mathrm{~A}$ and $15 \% \mathrm{~B} ; 8.0 \mathrm{~min}, 80 \% \mathrm{~A}$ and $20 \% \mathrm{~B} ; 12 \mathrm{~min}, 75 \% \mathrm{~A}$ and $25 \% \mathrm{~B} ; 16 \mathrm{~min}, 70 \% \mathrm{~A}$ and $30 \% \mathrm{~B}$; $25 \mathrm{~min}, 60 \% \mathrm{~A}$ and $40 \% \mathrm{~B} ; 40 \mathrm{~min}, 60 \% \mathrm{~A}$ and $40 \% \mathrm{~B}$. The eluates were detected at 280 and $350 \mathrm{~nm}$. The concentration of identified phenols was calculated with external standards method.

2.6. Antioxidant Activity. Antioxidant activity was measured by 1,1-diphenyl-2-picrylhydrazyl (DPPH) solution $\left(6 \cdot 10^{-5} \mathrm{M}\right.$ in methanol) and the free radical scavenging activity was expressed as the $\mathrm{EC}_{50}$ value: the volume $(\mu \mathrm{L})$ required to reduce $50 \%$ of the initial DPPH radical activity. Total antioxidant activity of pomegranate juice was determined by the 1,1-diphenyl-2-picrylhydrazyl (DPPH) method [22]. Onion extracts in different concentrations were mixed with $6 \cdot 10^{-5} \mathrm{M}$ methanol solution of DPPH radical. The mixture was shaken vigorously and left to stand for $30 \mathrm{~min}$ in the dark at room temperature. After the reaction was allowed to take place in the dark for $30 \mathrm{~min}$, the absorbance at $517 \mathrm{~nm}$ was recorded to determine the concentration of remaining DPPH.

The antioxidant activity was expressed according to Albanese et al. [23] as percentage inhibition of DPPH and then calculated according to the following equation:

$$
\% \text { inhibition of DPPH }=\left[\frac{\left(A_{C(0)}-A_{S(t)}\right)}{A_{C(0)}}\right] * 100,
$$

where $A_{C(0)}$ is the absorbance of the control at $t=0 \mathrm{~min}$ and $A_{S(t)}$ is the absorbance of sample at $t=30 \mathrm{~min}$. The free radical scavenging activity determined by DPPH was expressed as the $\mathrm{EC}_{50}$ value: $\mathrm{mg}$ of the extract per $\mathrm{mL}$ required to reduce $50 \%$ of the initial DPPH radical activity.

2.7. Pungency Analysis. Pungency of onions was determined as enzymatically (alliinase) produced pyruvate (EPY) by colourimetric analysis according to Schwimmer and Weston (1961) with slight modifications. Onion landraces were sliced in half longitudinally: $50 \mathrm{~g}$ was homogenized by Ultra-Turrax blender (T25, IKA Werke, Staufen, Germany) with $50 \mathrm{~mL}$ of distilled water for the determination of total pyruvate alliinase produced, whereas $50 \mathrm{~g}$ of onions was pretreated with $50 \mathrm{~mL}$ of $5 \%$ trichloroacetic acid solution to inactivate the alliinase in order to quantify pyruvate basal level. Both mixtures were left at room temperature for $15 \mathrm{~min}$ and filtered with Whatman filter paper (grade 1) and $10 \mathrm{~mL}$ of the filtrate was diluted ten times with bidistilled water. One millilitre of sample was placed in a reaction tube with $1 \mathrm{~mL}$ of 2,4dinitrophenyl hydrazine (DNPH) solution (0.0125\% DNPH in $2 \mathrm{M} \mathrm{HCl}$ ) and $1 \mathrm{~mL}$ of bidistilled water. Reaction tube was vortexed and placed in a water bath at $37^{\circ} \mathrm{C}$ for 10 minutes. After the incubation time, $5 \mathrm{~mL}$ of $0.6 \mathrm{M} \mathrm{NaOH}$ was added to the tube and allowed to stand for $5 \mathrm{~min}$. The DNP hydrazine derivative of pyruvate was measured using PerkinElmer Lambda $25 \mathrm{UV}$-Vis spectrometer at $420 \mathrm{~nm}$. Enzymatically (alliinase) produced pyruvate (EPY) in each sample was calculated from the difference of total and basal concentration of pyruvate. A blank sample was prepared with $2 \mathrm{~mL}$ of water and $1 \mathrm{~mL}$ of DNPH; standards were prepared replacing onion sample with $1 \mathrm{~mL}$ of sodium pyruvate solution, ranging from 20 to $100 \mu \mathrm{M}$.

2.8. Sugars Analysis. Sugars were determined by HPLC (Hewlett Packard, mod. 79852, USA) [21]. The HPLC system was equipped with $4.6 \times 250 \mathrm{~mm}(60 \AA, 4 \mu \mathrm{m})$ carbohydratecartridge column (Waters, USA). The mobile phase was an acetonitrile-water solution $(75: 25)$, with a flow rate of $1.2 \mathrm{~mL} / \mathrm{min}$ and a column temperature of $60^{\circ} \mathrm{C}$. Peaks were detected by a refractive index detector (Hewlett Packard, mod. 100, USA) and concentrations were calculated with external standards method.

2.9. Organic Acids Analysis. $1 \mathrm{~g}$ of fresh onion was added to distilled water up to $10 \mathrm{~mL}$ and homogenized in an UltraTurrax blender (T25, IKA Werke, Staufen, Germany) for $2 \mathrm{~min}$. The samples were centrifuged at $4000 \mathrm{rpm}$ for $10 \mathrm{~min}$ and filtered through $0.45 \mu \mathrm{m}$ syringe cellulose filter (Millipore, USA) before ion exchange chromatography analysis. The apparatus (Dionex Corp., USA) was equipped with an ED 500 electrochemical detector, Ionpac AS11 column (250× $4 \mathrm{~mm})$, and Ionpac AS11 Guard $(50 \times 4 \mathrm{~mm})$. The elution phase at $0.5 \mathrm{~mL} / \mathrm{min}$ was bidistilled water (E1) and $\mathrm{NaOH}$ $100 \mathrm{mM}$ (E2) for a total running time of $25 \mathrm{~min}$, using the following gradient: from $93 \% \mathrm{E} 1$ at time 0 to $65 \% \mathrm{E} 1$ at $20 \mathrm{~min}$ and then to $93 \% \mathrm{E} 1$ in $5 \mathrm{~min}$ [24]. The organic acids were identified by the overlapping of their retention time with those of commercial standard acids prepared from $1 \mathrm{~g} / \mathrm{L}$ stock solution and diluted to the required concentration before use. A calibration curve of organic acid standards was obtained and used for quantitative analysis. Acquisition and integration of chromatograms were performed with Peaknet G4G1T0 (Dionex Corp.) software.

2.10. Statistical Analysis. Analysis of parameters investigated was carried out on five different samples belonging to each onion group. Results were reported as the mean and standard deviation. The analysis of variance (ANOVA) was applied to the data. The least significant differences were obtained using an LSD test $(p \leq 0.05)$. Statistical analysis was performed using SPSS version 13.0 for Windows (SPSS, Inc., Chicago, IL, USA). 


\section{Results and Discussion}

A total of 22 compounds (Table 1) were identified in the volatile fraction of onion samples belonging to the following chemical classes: sulfur-containing compounds (S-compounds), aldehydes, and ketones.

S-compounds were the main volatile compounds of the onion profile [11] which in our study ranged from a minimum of $207.87 \mathrm{mg} / \mathrm{Kg}$ in Febbrarese landrace to a maximum of $1459.40 \mathrm{mg} / \mathrm{Kg}$ in Aprilatica one, corresponding to $63 \%$ and $74 \%$ of total volatile compounds, respectively. Nine out of fifteen S-compounds were di- and trisulfides and were the most numerous. These results were in agreement with Lanzotti [25] who proved that di- and trisulfides were the main compounds in the volatile fraction of the onion isolated by steam distillation. Furthermore, the volatile S-compounds of Bianca di Pompei onion landraces were the typical molecules of the volatile fraction characterizing the onion's pungent flavour [26-29]. Other compounds, aldehydes and ketones, were found in a smaller amount ranging between 17-21\% and $3-7 \%$ of the total volatile compounds, respectively, in landrace samples.

The overall content of volatile compounds seems to be influenced by growth cycle and harvest month which is a function of temperature. Metabolite compositions in onions are strongly affected by climate conditions, in particular by air temperature [30]. In fact, Febbrarese and Marzatica landraces grown and harvested in colder winter months showed lower concentrations of total volatile compounds than those found in Aprilatica, Maggiaiola, and Giugnese, which were characterized by a milder crop temperature. These three onion landraces showed a concentration of volatile compounds almost five times higher than that in Febbrarese and Marzatica. Likewise, aldehydes, ketones, and S-compounds increased from Febbrarese to Giugnese; in particular, Giugnese showed the highest amounts equal to 395.28 and $133.46 \mathrm{mg} / \mathrm{kg}$ for aldehydes and ketones, respectively, while S-compounds content was maximum in Aprilatica (1459.40 mg/kg).

For all the investigated onion landraces, quantitative analysis showed that di- and trisulfides, such as cis- and trans-methyl-1-propenyl disulfide, methyl-2-propenyl disulfide, dipropyl disulfide, cis- and trans-propenyl propyl disulfide, methyl propyl trisulfide, and dipropyl trisulfide, were the largest part, whose sum represents about $60 \%$ of Scompounds.

$\mathrm{Di}$ - and trisulfides increased in landraces harvested in spring months (Aprilatica, Maggiaiola, and Giugnese) in comparison to those detected in Febbrarese and Marzatica landraces harvested in colder winter months.

According to Lanzotti (2006), di- and trisulfides were formed by the degradation of thiosulfinates whose biosynthetic pathway came from the condensation reactions of alk(en)yl-sulfenic acids (e.g., Z,E-propanethial S-oxide or lachrymator factor). The amount of alk(en)yl-sulfenic acids (the lachrymator factor) was closely linked to the concentration of the aroma precursors: S-alkenyl cysteine sulfoxides (ACSOs). The higher content of di- and trisulfides than other volatile compounds in onion samples cultivated during warmer spring months was probably due to an increase of
S-alkenyl cysteine sulfoxides (ACSOs), according to Randle and Coolong [31] who proved that growth temperature affected ACSOs concentration of Granex 33 onion. In particular, they recorded that ACSO concentrations from bulbs grown at $15.6^{\circ} \mathrm{C}$ were roughly a third of those grown at $32.2^{\circ} \mathrm{C}$. Among di- and trisulfide compounds, methyl propyl trisulfide was the most abundant compound for all onion samples investigated, followed by trans-methyl-1propenyl disulfide. A similar result has been documented by Arnault et al. [32] who reported that S-compounds such as thiosulfonates, propyl-containing disulfides and trisulfides, propenyl-containing disulfides and trisulfides, and thiophene derivates mainly contributed to the volatile compounds of onion.

About the aldehydes class, four compounds were detected in the volatile pattern of onion samples except for 2-methyl2-pentenal which was not detected in Febbrarese landrace. Aldehydes content was different $(p \leq 0.05)$ for the five onion landraces investigated and it increased in landraces harvested from February (Febbrarese) to June (Giugnese). Among the aldehydes, furfuraldehyde was the most abundant in all samples, and its highest content $(p \leq 0.05)$ was found in Aprilatica landrace. Propionaldehyde and 2-methyl-2-pentenal contents were different $(p \leq 0.05)$ in landraces samples: the highest values were in Aprilatica landrace, followed by Maggiaiola and Giugnese. These aldehydes, together with di- and trisulfide compounds, arose from the lachrymator factor [28, 33 ] as well as the pungency and the overall flavour of onion.

The other volatile compounds were two ketones and furfuryl alcohol (Table 1). The 1,2-cyclopentanedione concentration differed at harvest time: in spring months, Aprilatica, Maggiaiola, and Giugnese landraces had a higher content ( $p \leq$ 0.05 ) than those yielded in winter (Febbrarese and Marzatica). The butyrolactone compound was detected only in landraces harvested in spring months (Aprilatica, Maggiaiola, and Giugnese).

Total phenols, quantified in the onion samples, were reported in Table 2 . The concentration ranged from a minimum of 4.75 in Febbrarese to a maximum of 5.31 in Giugnese. The results were in accordance with Santas et al. (2008) and Prakash et al. (2007) who evaluated white Spanish and red, violet, and green onion varieties, respectively.

The onion landraces were also studied for their specific phenols composition (Figure 1 and Table 2). For all landraces, the most abundant phenol was gallic acid, whose quantity changes from 55.66 to $64.90 \mu \mathrm{g} / \mathrm{g}$ dw in Febbrarese and Giugnese, respectively. Among identified phenols, quercetin has an important role from a nutritional point of view. Quercetin is the aglycone form of several other flavonoid glycosides such as rutin and quercitrin that are found in citrus fruits, buckwheat, and onions [35]. Functional benefits of quercetin include anti-inflammatory activity, antihistamine effect, allergy medication, and anticancer and antivirus activities. It has also been claimed to regulate blood pressure in hypertensive subjects [36].

In our samples, this flavonol was found to be between 6.98 and $8.14 \mu \mathrm{g} / \mathrm{g}$; higher amounts were detected by Prakash et al. (2007) who studied quercetin in four (red, white, violet, and green) onion varieties. 


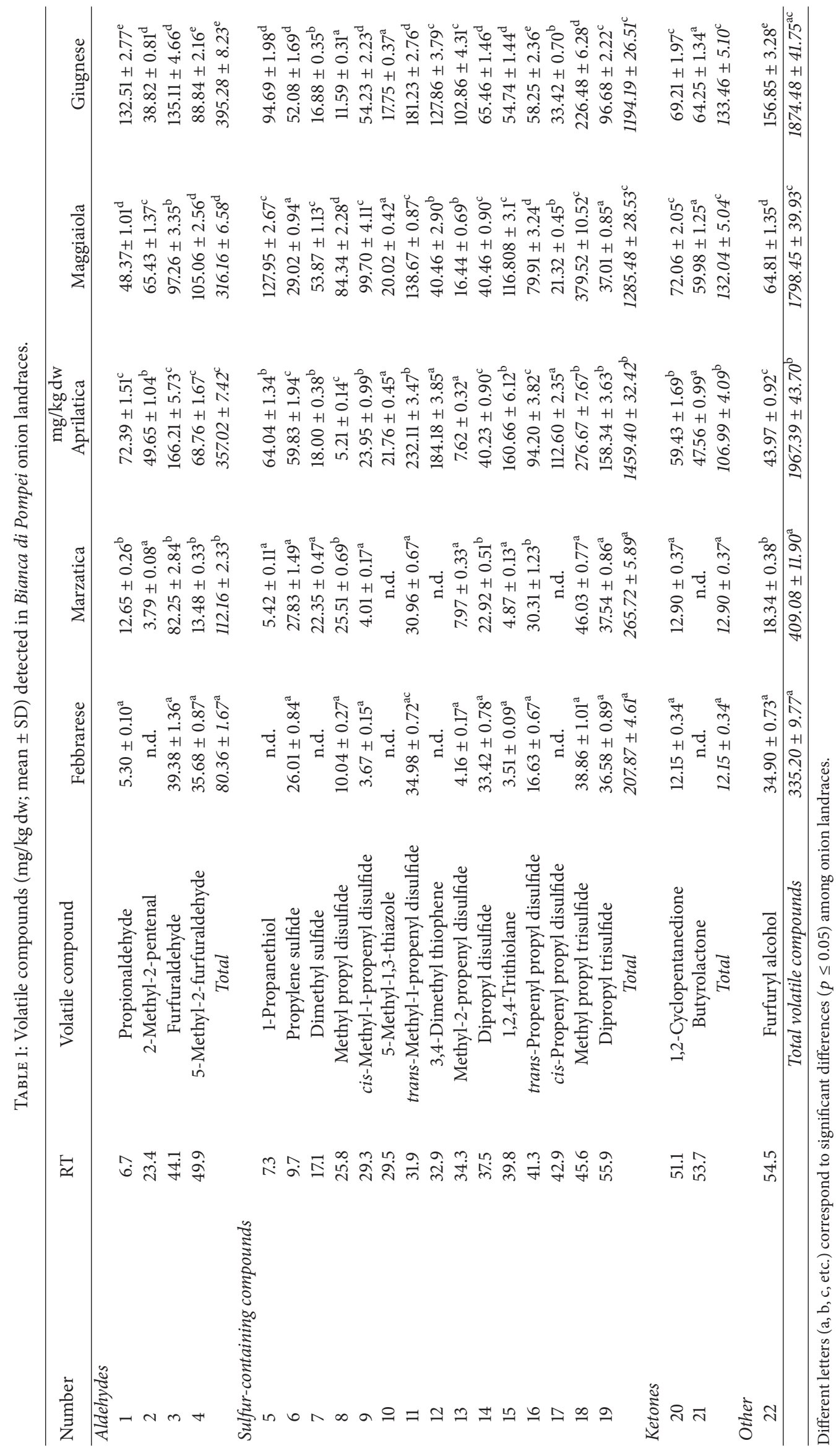


TABLE 2: Phenols (mg/g dw; mean \pm SD), antioxidant activity $\left(E_{50}\right.$ mg extract/mL; mean $\left.\pm \mathrm{SD}\right)$, and total phenols (mg GAE/g dw) of Bianca di Pompei onion landraces.

\begin{tabular}{|c|c|c|c|c|c|}
\hline & Febbrarese & Marzatica & Aprilatica & Maggiaiola & Giugnese \\
\hline \multicolumn{6}{|l|}{ Phenols $(m g / g d w)$} \\
\hline Gallic acid & $55.66 \pm 2.30^{\mathrm{a}}$ & $59.56 \pm 1.10^{\mathrm{ab}}$ & $61.23 \pm 2.50^{\mathrm{b}}$ & $61.94 \pm 1.91^{\mathrm{b}}$ & $64.90 \pm 1.22^{\mathrm{b}}$ \\
\hline Ferulic acid & $1.52 \pm 0.20^{\mathrm{a}}$ & $1.62 \pm 0.25^{\mathrm{a}}$ & $1.67 \pm 0.41^{\mathrm{a}}$ & $1.69 \pm 0.19^{\mathrm{a}}$ & $1.77 \pm 0.30^{\mathrm{a}}$ \\
\hline Quercetin & $6.98 \pm 0.42^{\mathrm{a}}$ & $7.47 \pm 0.30^{\mathrm{b}}$ & $7.68 \pm 0.28^{\mathrm{b}}$ & $7.77 \pm 0.30^{\mathrm{b}}$ & $8.14 \pm 0.20^{\mathrm{b}}$ \\
\hline Kaempferol & $1.62 \pm 0.33^{\mathrm{a}}$ & $1.73 \pm 0.27^{\mathrm{a}}$ & $1.78 \pm 0.15^{\mathrm{a}}$ & $1.80 \pm 0.21^{\mathrm{a}}$ & $1.89 \pm 0.32^{\mathrm{a}}$ \\
\hline Chlorogenic acid & $0.84 \pm 0.06^{\mathrm{a}}$ & $0.90 \pm 0.02^{\mathrm{a}}$ & $0.92 \pm 0.08^{\mathrm{a}}$ & $0.93 \pm 0.04^{\mathrm{a}}$ & $0.98 \pm 0.07^{\mathrm{a}}$ \\
\hline \multicolumn{6}{|l|}{ Antioxidant activity } \\
\hline $\mathrm{EC}_{50}(\mathrm{mg}$ extract $/ \mathrm{mL})$ & $18.80 \pm 1.0^{\mathrm{a}}$ & $18.50 \pm 0.50^{\mathrm{a}}$ & $20.90 \pm 0.60^{\mathrm{b}}$ & $20.25 \pm 0.40^{\mathrm{b}}$ & $21.27 \pm 0.8^{\mathrm{b}}$ \\
\hline Total phenols ( $m g$ GAE/g dw) & $4.75 \pm 0.24^{\mathrm{a}}$ & $4.90 \pm 0.10^{\mathrm{a}}$ & $5.14 \pm 0.35^{\mathrm{a}}$ & $5.06 \pm 0.28^{\mathrm{a}}$ & $5.31 \pm 0.30^{\mathrm{a}}$ \\
\hline
\end{tabular}

Different letters $(\mathrm{a}, \mathrm{b})$ correspond to significant differences $(p \leq 0.05)$ among onion landraces.

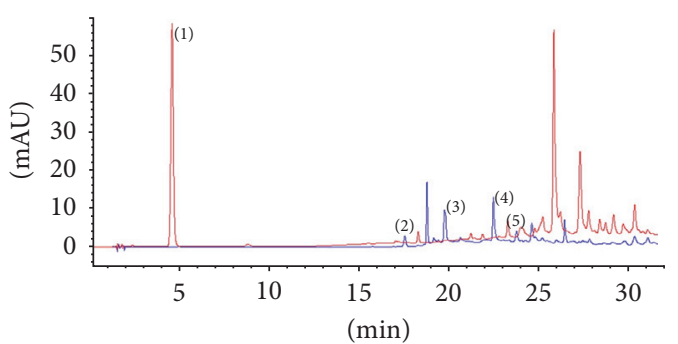

(1) Gallic acid

(2) Chlorogenic acid

(3) Ferulic acid

(4) Quercetin

(5) Kaempferol

Figure 1: Chromatograms of phenols in onion samples at 280 and $350 \mathrm{~nm}$ (red and blue lines, resp.).

All the other phenols increased in landraces harvested in spring months. Our results highlighted the notion that the quantity of phenolic pool may change not only with the cultivar as reported in the literature $[6,34]$ but also with the growth stage and environmental conditions.

The antioxidant activity varied from 19.00 to $21.27 \mathrm{mg}$ of extract $/ \mathrm{mL}$ (Table 2). Our results were in agreement with previous $\mathrm{EC}_{50}$ data on white onions [6] and consistent with quali-quantitative phenols previously described. In fact, the highest values were found for Aprilatica, Maggiaiola, and Giugnese without significant differences $(p \leq 0.05)$ among them.

It is generally accepted that there is a high correlation between levels of enzymatically produced pyruvate (EPY) present in onions and the perception of pungency [12]. The investigation of this parameter was important to estimate the potential flavour and to define the aroma characteristics of various onion cvs. Classification of onions according to pungency was proposed as follows: low, $0-3 \mu \mathrm{mol}$ of pyruvic acid/g; moderate, 3-7 $\mu \mathrm{mol}$ of pyruvic acid/g; and high, higher than $7 \mu \mathrm{mol}$ of pyruvic acid/g [37].

Herein, all onion landraces had high pungency values expressed by EPY amount, ranging from 9 to $14 \mu \mathrm{mol} / \mathrm{g} \mathrm{FW}$.
Significant differences $(p \leq 0.05)$ were found among the five landraces with the highest pungency level in Aprilatica landrace.

In order to define the sensory profile of onion, the sugars content was investigated. Three soluble sugars, sucrose, glucose, and fructose, were detected in the five onion landraces (Table 3). Other water soluble sugars (oligosaccharides of fructose, named fructans) were found by Davis et al. (2007) in the characterization of different onion cvs cultivated in the United Kingdom.

The total content of soluble sugars in Bianca di Pompei landraces changed from 3 to $5 \mathrm{~g} / 100 \mathrm{~g} \mathrm{FW}$ according to the ranges reported in the literature for other onion cultivars [38$42]$. No statistical difference ( $p \leq 0.05)$ was found among the onion landraces as regards fructose, while significant differences ( $p \leq 0.05$ ) were found for glucose, sucrose, and the total sugar content. Anyway, these differences do not influence the sweetness of the onion because the pungency values are higher than $4 \mu \mathrm{mol} / \mathrm{g} \mathrm{FW}$, a medium-low level that would allow appreciating these differences during taste, as reported by Crowther et al. [43].

Seven organic acids were identified and quantified in onion samples (Table 3). The results were in accordance with those found in Recas cv onions [40], in four onion Greek cvs [39], and in six onion Spanish cvs [41] with fumaric and glutamic acids too. The main acids that contribute mostly to edible flesh acidity are malic $(78.94-57.61 \mathrm{mg} / 100 \mathrm{~g} \mathrm{fw})$ and citric $(63.32-19.70 \mathrm{mg} / 100 \mathrm{~g} \mathrm{fw})$ acids. Similar results were reported by Caruso et al. [44].

Malic acid was the most abundant organic acid for all onion samples except for Febbrarese landrace, where citric acid was the abundant organic acid. Significant differences $(p \leq 0.05)$ were found among all landraces for organic acids amount, probably due to a different activation level of multiple metabolic pathways, among which the Cycle of Krebs is the main one. Regarding ascorbic acid, it contributes to the nutritional value of the onion with respect to the other acids; the highest amount was found in Aprilatica landraces, followed by Maggiaiola and Giugnese, suggesting that the samples harvested in spring months had higher vit. $\mathrm{C}$ than those harvested in winter. Furthermore, ascorbic acid concentration in Aprilatica, Maggiaiola, and Giugnese 
TABLE 3: Organic acids (mg/100 g fw; mean \pm SD), sugars ( $\mathrm{g} / 100 \mathrm{~g}$ fw; mean \pm SD) content, and pungency ( $\mu$ mol/g fresh weight) of Bianca di Pompei onion landraces.

\begin{tabular}{|c|c|c|c|c|c|}
\hline & Febbrarese & Marzatica & Aprilatica & Maggiaiola & Giugnese \\
\hline \multicolumn{6}{|l|}{ Organic acids } \\
\hline Malic acid & $60.43 \pm 6.53^{\mathrm{a}}$ & $66.33 \pm 6.61^{\mathrm{a}}$ & $61.85 \pm 4.50^{\mathrm{a}}$ & $57.61 \pm 3.34^{\mathrm{a}}$ & $78.94 \pm 2.10^{\mathrm{b}}$ \\
\hline Citric acid & $63.32 \pm 5.90^{\mathrm{a}}$ & $57.05 \pm 3.24^{\mathrm{a}}$ & $54.55 \pm 5.43^{\mathrm{a}}$ & $34.46 \pm 5.38^{\mathrm{b}}$ & $19.70 \pm 3.95^{\mathrm{c}}$ \\
\hline Tartaric acid & $13.93 \pm 2.75^{\mathrm{a}}$ & $6.10 \pm 1.21^{b}$ & $16.15 \pm 1.25^{\mathrm{a}}$ & $25.88 \pm 4.57^{\mathrm{c}}$ & $12.02 \pm 2.85^{\mathrm{a}}$ \\
\hline Oxalic acid & $30.43 \pm 2.97^{\mathrm{a}}$ & $19.93 \pm 1.51^{\mathrm{b}}$ & $13.60 \pm 1.41^{\mathrm{c}}$ & $12.21 \pm 1.90^{\mathrm{c}}$ & $10.68 \pm 2.92^{c}$ \\
\hline Ascorbic acid & $4.63 \pm 0.85^{\mathrm{a}}$ & $4.85 \pm 0.15^{\mathrm{a}}$ & $21.65 \pm 2.80^{\mathrm{b}}$ & $17.69 \pm 1.96^{\mathrm{c}}$ & $14.80 \pm 1.73^{c}$ \\
\hline Succinic acid & $11.55 \pm 1.04^{\mathrm{a}}$ & $9.28 \pm 2.72^{\mathrm{a}}$ & $19.40 \pm 0.89^{\mathrm{b}}$ & $23.35 \pm 2.21^{c}$ & $14.34 \pm 0.82^{\mathrm{ad}}$ \\
\hline Pyruvic acid & $1.07 \pm 0.44^{\mathrm{a}}$ & $1.18 \pm 0.66^{\mathrm{a}}$ & $0.35 \pm 0.09^{\mathrm{a}}$ & $0.76 \pm 0.21^{\mathrm{a}}$ & $0.50 \pm 0.10^{\mathrm{a}}$ \\
\hline Total & $185.36 \pm 52.83^{\mathrm{a}}$ & $164.72 \pm 30.07^{\mathrm{a}}$ & $187.55 \pm 55.79^{\mathrm{a}}$ & $171.96 \pm 52.16^{\mathrm{a}}$ & $150.98 \pm 21.79^{\mathrm{a}}$ \\
\hline Pungency (EPY) & $9.31 \pm 0.97^{\mathrm{a}}$ & $10.01 \pm 0.31^{\mathrm{a}}$ & $14.34 \pm 0.13^{\mathrm{b}}$ & $13.00 \pm 0.84^{\mathrm{c}}$ & $12.53 \pm 0.27^{\mathrm{c}}$ \\
\hline \multicolumn{6}{|l|}{ Soluble sugars } \\
\hline Fructose & $1.74 \pm 0.42^{\mathrm{a}}$ & $1.66 \pm 0.62^{\mathrm{a}}$ & $2.11 \pm 0.23^{\mathrm{a}}$ & $2.00 \pm 0.60^{\mathrm{a}}$ & $2.26 \pm 0.70^{\mathrm{a}}$ \\
\hline Glucose & $1.09 \pm 0.18^{\mathrm{a}}$ & $0.88 \pm 0.43^{\mathrm{a}}$ & $1.97 \pm 0.09^{\mathrm{b}}$ & $1.79 \pm 0.54^{\mathrm{b}}$ & $2.00 \pm 0.27^{\mathrm{b}}$ \\
\hline Sucrose & $0.90 \pm 0.11^{\mathrm{a}}$ & $0.81 \pm 0.21^{\mathrm{a}}$ & $1.76 \pm 0.36^{\mathrm{b}}$ & $1.04 \pm 0.27^{\mathrm{ac}}$ & $1.21 \pm 0.24^{c}$ \\
\hline Total & $3.73 \pm 0.64^{\mathrm{ac}}$ & $3.35 \pm 1.16^{\mathrm{a}}$ & $5.83 \pm 0.67^{\mathrm{b}}$ & $4.84 \pm 1.32^{\mathrm{bc}}$ & $5.46 \pm 1.09^{\mathrm{b}}$ \\
\hline
\end{tabular}

Different letters (a, b, c, etc.) correspond to significant differences $(p \leq 0.05)$ among onion landraces.

ranged from 14.80 to $21.65 \mathrm{mg} / 100 \mathrm{~g} \mathrm{fw}$, higher than that reported for other onion cultivars (range: $1.2-6 \mathrm{mg} / 100 \mathrm{~g} \mathrm{fw}$ ) [41].

\section{Conclusions}

In our study, we highlighted the differences, of the most important quality parameters, existing among five onion landraces belonging to "Bianca di Pompei" cv. In regard to the investigation of onion volatile compounds, the volatile fraction was clearly dominated by sulfur compounds. These compounds seemed to be influenced by harvest month and so from by temperature of growth; in fact, the landraces Aprilatica, Maggiaiola, and Giugnese grown during the milder time period showed higher amount of sulfur compounds than those registered in Febbrarese and Marzatica cultivated and harvested in winter months. Similarly, total phenols, phenols profile, and antioxidant activity increased in onion landraces harvested in spring months. The pungency of all landraces was found to be high according to pungency classification of the onion. Also, for this parameter, the highest values were found for onion samples grown during mild months. Thus, even if the genetic factors as reported in the literature are predominant for the expression of quality and sensory parameters, this study highlights the notion that also the external factors, such as the period of growth, influence some of the sensory attributes such as aroma and taste.

\section{Competing Interests}

The authors declare that there are no competing interests regarding the publication of this paper.

\section{Acknowledgments}

This research was financially supported by "Ministero dell'Istruzione, dell'Università e della Ricerca" and Regione Campania as part of project "AGRIGENET-Network per la Salvaguardia e la Gestione delle Risorse Genetiche AgroAlimentari Campane" (PSR 2007-2013, Misura 214).

\section{References}

[1] B. Bindu and B. Podikunju, "Performance evaluation of onion (Allium Cepa L. Var. Cepa) varieties for their suitability in kollam district," International Journal of Research in Agricultural Sciences, vol. 1, no. 1, pp. 18-20, 2015.

[2] R. Slimestad, T. Fossen, and I. M. Vågen, "Reviews. Onions: a source of unique dietary flavonoids," Journal of Agricultural and Food Chemistry, vol. 55, no. 25, pp. 10067-10080, 2007.

[3] G. Griffiths, L. Trueman, T. Crowther, B. Thomas, and B. Smith, "Onions-a global benefit to health," Phytotherapy Research, vol. 16, no. 7, pp. 603-615, 2002.

[4] R. M. Pérez-Gregorio, M. S. García-Falcón, J. Simal-Gándara, A. S. Rodrigues, and D. P. F. Almeida, "Identification and quantification of flavonoids in traditional cultivars of red and white onions at harvest," Journal of Food Composition and Analysis, vol. 23, no. 6, pp. 592-598, 2010.

[5] J. Santas, M. P. Almajano, and R. Carbó, "Antimicrobial and antioxidant activity of crude onion (Allium cepa, L.) extracts," International Journal of Food Science and Technology, vol. 45, no. 2, pp. 403-409, 2010.

[6] D. Prakash, B. N. Singh, and G. Upadhyay, "Antioxidant and free radical scavenging activities of phenols from onion (Allium cepa)," Food Chemistry, vol. 102, no. 4, pp. 1389-1393, 2007.

[7] B. De Ancos, C. Colina-Coca, D. Gonzalex-Pena, and C. Sanchez-Moreno, "Bioactive compounds from vegetable and fruit 
by-products," in Biotechnology of Bioactive Compounds. Sources and Applications. Section I, V. K. Gupta and M. G. Tuohy, Eds., pp. 3-36, Wiley Blackwell, 2015.

[8] V. Benítez, E. Mollá, M. A. Martín-Cabrejasa et al., "Study of bioactive compound content in different onion sections," Plant Foods for Human Nutrition, vol. 66, no. 1, pp. 48-57, 2011.

[9] P. Rose, M. Whiteman, P. K. Moore, and Y. Z. Zhu, "Bioactive S-alk(en)yl cysteine sulfoxide metabolites in the genus Allium: the chemistry of potential therapeutic agents," Natural Product Reports, vol. 22, no. 3, pp. 351-368, 2005.

[10] D. E. Pszczola, "Antimicrobials: setting up additional hurdles to ensure food safety," Food Technology, vol. 56, no. 6, pp. 99-107, 2002.

[11] E. Block, "The organosulfur chemistry of the genus Alliumimplications for the organic chemistry of sulfur," Angewandte Chemie-International Edition, vol. 31, no. 9, pp. 1135-1178, 1992.

[12] S. Schwimmer and W. J. Weston, "Onion flavor and odor: enzymatic development of pyruvic acid in onion as a measure of pungency," Journal of Agricultural and Food Chemistry, vol. 9, no. 4, pp. 301-304, 1961.

[13] J. R. Bacon, G. K. Moates, A. Ng, M. J. C. Rhodes, A. C. Smith, and K. W. Waldron, "Quantitative analysis of flavour precursors and pyruvate levels in different tissues and cultivars of onion (Allium cepa)," Food Chemistry, vol. 64, no. 2, pp. 257-261, 1999.

[14] K. S. Yoo, L. Pike, K. Crosby, R. Jones, and D. Leskovar, "Differences in onion pungency due to cultivars, growth environment, and bulb sizes," Scientia Horticulturae, vol. 110, no. 2, pp. 144149, 2006.

[15] G. A. Chope, L. A. Terry, and P. J. White, "Preharvest application of exogenous abscisic acid (ABA) or an ABA analogue does not affect endogenous ABA concentration of onion bulbs," Plant Growth Regulation, vol. 52, no. 2, pp. 117-129, 2007.

[16] K. R. Soumya, M. T. Teena, and S. Sudha, "Evaluation of cytotoxic effects of synthetic pesticide 'Attack' on Root Meristems of Allium cepa L," South Indian Journal of Biological Sciences, vol. 2, no. 1, p. 35, 2016.

[17] L. A. Terry, K. A. Law, K. J. Hipwood, and P. H. Bellamy, "Nonstructural carbohydrate profiles in onion bulbs influence taste preference," in Proceedings of the Information and Technology for Sustainable Fruit and Vegetable Production (Frutic '05), Montpellier, France, September 2005.

[18] G. Mennella, V. O. Sanaja', A. D’Alessandro, and A. Desiderio, "Biochemical characterization of white onion landraces (Allium cepa L.) through HPLC analysis of endosperm seed proteins," Euphytica, vol. 141, no. 1-2, pp. 169-180, 2005.

[19] D. Albanese, G. Attanasio, L. Cinquanta, and M. Di Matteo, "Volatile compounds in red wines processed on an industrial scale by short pre-fermentative cold maceration," Food and Bioprocess Technology, vol. 6, no. 11, pp. 3266-3272, 2013.

[20] V. Singleton and J. Rossi Jr., "Colorimetry of total phenolics with phosphomolybdic phosphotungstic acid reagents," American Journal of Enology and Viticulture, vol. 16, pp. 144-158, 1965.

[21] L. Cinquanta, D. Albanese, F. De Curtis, F. Malvano, A. Crescitelli, and M. Di Matteo, "Rapid assessment of gray mold (Botrytis cinerea) infection in grapes with a biosensor system," American Journal of Enology and Viticulture, vol. 66, no. 4, pp. 502-508, 2015.

[22] W. Elfalleh, N. Nasri, N. Marzougui et al., "Physico-chemical properties and DPPH-ABTS scavenging activity of some local pomegranate (Punica granatum) ecotypes," International Journal of Food Sciences and Nutrition, vol. 60, no. 2, pp. 197-210, 2009.
[23] D. Albanese, L. Cinquanta, G. Cuccurullo, and M. Di Matteo, "Effects of microwave and hot-air drying methods on colour, $\beta$-carotene and radical scavenging activity of apricots," International Journal of Food Science and Technology, vol. 48, no. 6, pp. 1327-1333, 2013.

[24] L. Liguori, P. Russo, D. Albanese, and M. Di Matteo, "Evolution of quality parameters during red wine dealcoholization by osmotic distillation," Food Chemistry, vol. 140, no. 1-2, pp. 6875, 2013.

[25] V. Lanzotti, "The analysis of onion and garlic," Journal of Chromatography A, vol. 1112, no. 1-2, pp. 3-22, 2006.

[26] C. Colina-Coca, D. González-Peña, E. Vega, B. De Ancos, and C. Sánchez-Moreno, "Novel approach for the determination of volatile compounds in processed onion by headspace gas chromatography-mass spectrometry (HS GC-MS)," Talanta, vol. 103, pp. 137-144, 2013.

[27] R. Gyawalia, H. Seoa, H. Leeb et al., "Effect of $\gamma$-irradiation on volatile compounds of dried Welsh onion (Allium fistulosum L.)," Radiation Physics and Chemistry, vol. 75, pp. 322-328, 2006.

[28] N. Mondy, D. Duplat, J. P. Christides, I. Arnault, and J. Auger, "Aroma analysis of fresh and preserved onions and leek by dual solid-phase microextraction-liquid extraction and gas chromatography-mass spectrometry," Journal of Chromatography A, vol. 963, no. 1-2, pp. 89-93, 2002.

[29] R. Kubec, V. Drhova, and M. Jan Velisek, "Volatile compounds thermally generated from S-propylcysteine and S-propylcysteine sulfoxides aroma precursors of Allium vegetables," Journal of Agricultural and Food Chemistry, vol. 47, no. 3, pp. $1132-1138,1999$.

[30] A. M. Butt, Vegetative Growth, Morphogenesis and Carbohydrate Content of the Onion Plant as a Function of Light and Temperature under Field- and Controlled Conditions, Veenman, Wageningen, The Netherlands, 1968.

[31] W. M. Randle and T. W. Coolong, "Temperature influences flavour intensity and quality in 'Granex 33' onion," Journal of the American Society for Horticultural Science, vol. 128, no. 2, pp. 176-181, 2003.

[32] I. Arnault, N. Mondy, F. Cadoux, and J. Auger, "Possible interest of various sample transfer techniques for fast gas chromatography-mass spectrometric analysis of true onion volatiles," Journal of Chromatography A, vol. 896, no. 1-2, pp. 117-124, 2000.

[33] M. G. Jones, J. Hughes, A. Tregova, J. Milne, A. B. Tomsett, and H. A. Collin, "Biosynthesis of the flavour precursors of onion and garlic," Journal of Experimental Botany, vol. 55, no. 404, pp. 1903-1918, 2004.

[34] J. Santas, R. Carbó, M. H. Gordon, and M. P. Almajano, “Comparison of the antioxidant activity of two Spanish onion varieties," Food Chemistry, vol. 107, no. 3, pp. 1210-1216, 2008.

[35] D. P. Makris and J. T. Rossiter, "Domestic processing of onion bulbs (Allium cepa) and asparagus spears (Asparagus officinalis): effect on flavonol content and antioxidant status," Journal of Agricultural and Food Chemistry, vol. 49, no. 7, pp. 3216-3222, 2001.

[36] A. W. Boots, G. R. M. M. Haenen, and A. Bast, "Health effects of quercetin: from antioxidant to nutraceutical," European Journal of Pharmacology, vol. 585, no. 2-3, pp. 325-337, 2008.

[37] M. C. Pozzo Ardizzi, G. Aschkar, G. Pellejero et al., "Caracterizacion de distintos cultivares de cebolla (Allium cepa L.) segun las sustancias de reserva durante la conservacion en el Valle Inferior de rio Negro," in Proceedings of the Actas del 26th Congreso Argentino de Horticultura, Parana, Argentina, 2003. 
[38] F. Davis, L. A. Terry, G. A. Chope, and C. F. J. Faul, "Effect of extraction procedure on measured sugar concentrations in onion (Allium cepa L.) bulbs," Journal of Agricultural and Food Chemistry, vol. 55, no. 11, pp. 4299-4306, 2007.

[39] S. A. Petropoulos, Â. Fernandes, L. Barros, I. C. F. R. Ferreira, and G. Ntatsi, "Morphological, nutritional and chemical description of 'vatikiotiko', an onion local landrace from Greece," Food Chemistry, vol. 182, pp. 156-163, 2015.

[40] C. Colina-Coca, B. de Ancos, and C. Sánchez-Moreno, "Nutritional composition of processed onion: S-Alk(en)yl-l-cysteine Sulfoxides, Organic Acids, Sugars, Minerals, and Vitamin C," Food and Bioprocess Technology, vol. 7, no. 1, pp. 289-298, 2014.

[41] B. Rodríguez Galdón, C. Tascón Rodríguez, E. Rodríguez Rodríguez, and C. Díaz Romero, "Organic acid contents in onion cultivars (Allium cepa L.)," Journal of Agricultural and Food Chemistry, vol. 56, no. 15, pp. 6512-6519, 2008.

[42] C. S. Vavrina and D. A. Smittle, "Evaluating sweet onion cultivars for sugar concentrations and pungency," Hortsci, vol. 28, no. 8, pp. 804-806, 1993.

[43] T. Crowther, H. A. Collin, B. Smith, A. B. Tomsett, D. O'Connor, and M. G. Jones, "Assessment of the flavour of fresh uncooked onions by taste-panels and analysis of flavour precursors, pyruvate and sugars," Journal of the Science of Food and Agriculture, vol. 85, no. 1, pp. 112-120, 2005.

[44] G. Caruso, S. Conti, G. Villari et al., "Effects of transplanting time and plant density on yield, quality and antioxidant content of onion (Allium cepa L.) in southern Italy," Scientia Horticulturae, vol. 166, pp. 111-120, 2014. 

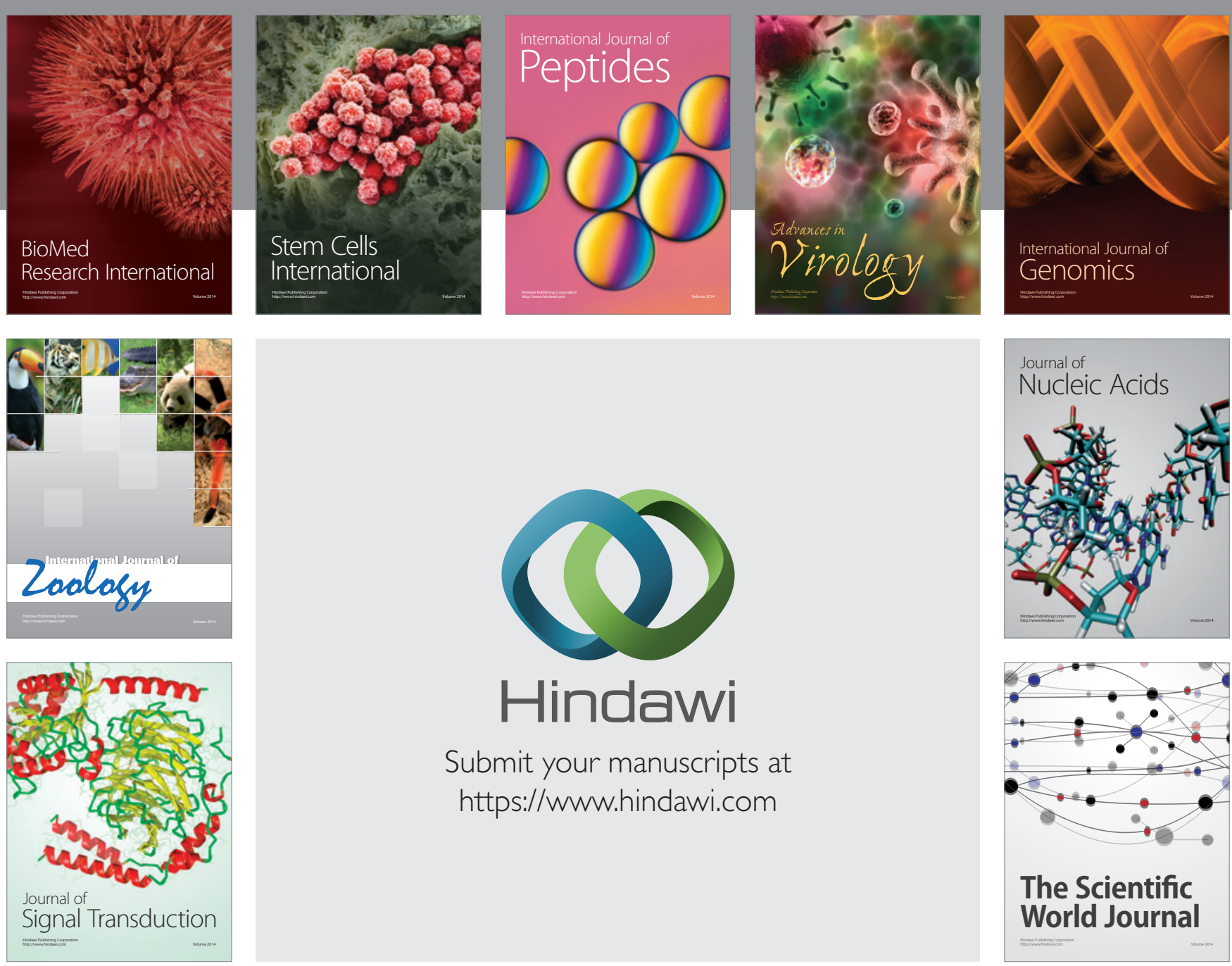

Submit your manuscripts at

https://www.hindawi.com
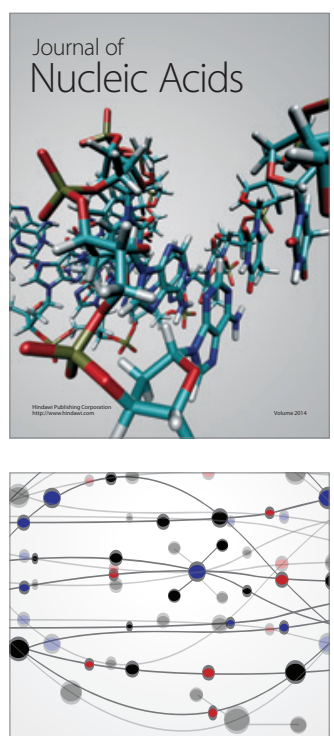

The Scientific World Journal
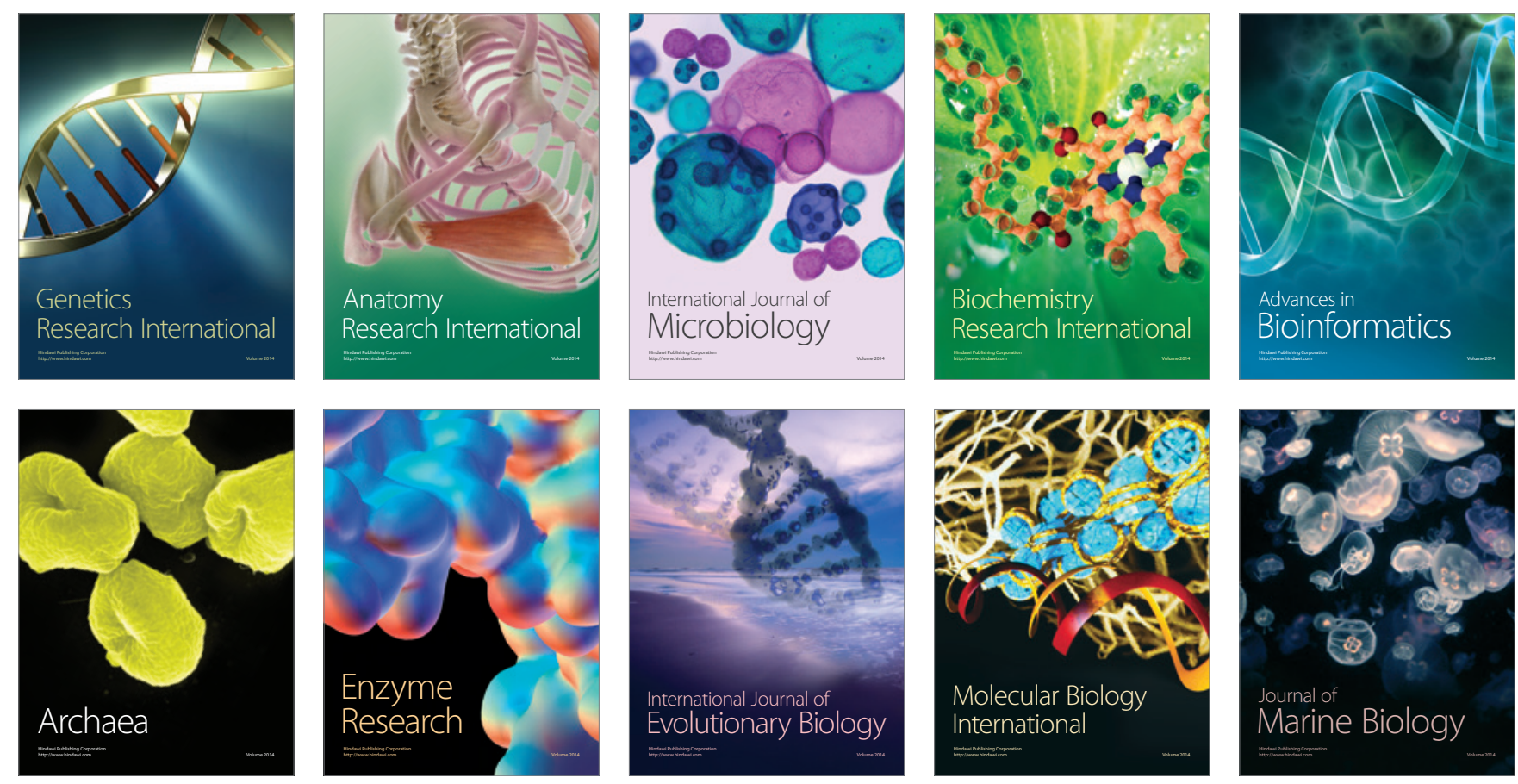